\title{
School political culture. What is it and how to study it?
}

\section{KEYWORDS}

school political culture, school culture, school as an organisation, civic competences

\begin{abstract}
Kamecka-Antczak Celina, School political culture. What is it and how to study it?. Culture - Society - Education no. 1(17) 2020, Poznań 2020, pp. 199-217, Adam Mickiewicz University Press. ISSN 2300-0422. DOI 10.14746/ kse.2020.17.9.2
\end{abstract}

The article is an attempt to create a new category in the study of the school, which is school political culture. Theoretical meta-analysis was used. In the first part, the author explains why she asks about school political culture. Based on the assumption that the school is an organisation, it justifies applying the tools of political culture to its study. The school as an organisation is a separate system of activity, with clearly defined goals, a specific division of labour among members of the school community and connectivity between elements with a certain degree of formalisation and hierarchy of power. A comparison of elements of the school's organisation with the basic elements of the political system is presented. The second part introduces the criteria that the theory of political culture should meet to become a theory that can be applied in school space. A meta-analysis of selected concepts of political culture: Gabriel Almond, Vilfredo Pareto and Zbigniew Blok (based on the developed criteria) allowed the selection of a leading theory. The results of meta-analysis are the subject of the third part of the article. The initial adaptation of the selected theory leading to the school specificity is a contribution to further scientific work on the development of a research tool allowing the classification of school political culture: of individual students, as well as the one dominating in the group. 


\section{Introduction}

The objective of the article is an attempt at answering the question: can the category of political culture be applied to studying schools, and if so, which concept of political culture should be chosen as a basis? The concepts of "school" and "political culture" are uniquely broad and difficult to define precisely. The concept of "political culture" itself is made up of two further terms that are difficult to define, namely "culture" and "politics". This introduces many doubts and fears as to whether the fusion of these two concepts would not lead the researcher astray. Surely, the use of the structured methodological approach of the theoretical meta-analysis shall allow one to broadly avoid any sort of related difficulties.

Political culture - in a very general sense - is a collection of convictions and actions of participants of a certain political system with respect to that system. Its scope covers ideas, values, political standards, customs, traditions, models of political behaviour, emotions with respect to political facts and criteria for their assessment (Sarnacki, 2016). Classical concepts of political culture apply to the state level, they ask about the attitude of the citizens towards components of the political system of a given state and about the determining factors for this attitude. Depending on the concepts, we shall be looking for signs of political culture in statements (conf. Almond, Verba, 1963) and/or actions (conf. Blok, 2009) of the members of a particular politically organised community. Determining factors of political culture shall be sought in the knowledge held by individuals, the value system adhered to by them or specifically in the system of organisation of a state, providing every participant with a real field of action. Some concepts of political culture consider only democratic systems (conf. Ferejohn, Rakove, Riley, 2001). Others provide the capacity to ask about political culture in other, non-democratic systems as well. Determining the properties of behaviour of the model citizen, concepts of political culture may at times become a tool of political indoctrination. Asking about the determining factors of such behaviour, they may develop patterns for ideal systems. The valuation of the types of political culture remains a point of dispute. Certain authors (conf. de Lazari, 2016) consider it valid to ask about the existence of the political culture within a certain community or the lack of such a culture. They define political culture as the culture of individuals characterised by civic activity.

Political culture may be studied as a whole, as dominant within a certain society, and as dominant within a specific social group or organisation. At that time, we may ask about the political culture of employees within a specific corporation or 
political culture of students, etc. The assumed objective is getting to know school political culture and determining the modes of its analyses. In this regard, I ask not about the dominant political culture of pupils with respect to state polity, but about the possibility of application of political culture concepts within the space of school. I ask about the political culture found at a given school and developed with respect to its own internal organisation. I ask the question: How to study a school's political culture thus defined? Can the idea of political culture be applied to the specifics of a school?

Interpreting school in the organisational perspective, it can be compared to any institution that is governed by its own laws and regulations, produces a common product and applies to people connected by institutional bonds (conf. Dymara, 2009). Wanting to understand school society, it may not be detached from culture in general, of which the school is a part; nor may be omitted the fact that as an organisation, it develops its own internal culture that we meet upon entering the school (Dernowska, Tłuściak-Deliowska, 2015). The use of tools of political culture with respect to a school requires the following questions to be posed: Is the school organised politically? Is the system of management of the school (as an organisation) similar to a political system used to manage the state? Looking for answers to these questions, a look was taken at the basic components of the political system (conf. Zieliński, 1999; Podolak, Żmigrodzki, 2013), attempting to find them within the school's organisation system:

1) an interdependent community, made up of groups of similar and contrary interests - the school community has common interests, it is composed of so-called groups of similar and contrary interests, e. g. pupil groups, parents, teachers, with each of these additionally being internally complex;

2) organisations, which through execution of influence and the acquisition and exercising of power represent the interests of these groups - at school this role is played by representatives of the student body, the parents' council, the school council, possibly e. g. extracurricular activity clubs;

3) state institutions holding monopoly to consider group interests, having at their disposal both tools of persuasion as well as those of compulsion and power - such bodies being the school management, the teachers' coun$\operatorname{cil}(?)$;

4) formal standards and customs governing mutual relations and the functioning of all constituent components of the system as well as political ideologies and strategies - in case of schools, these shall be externally determined norms based on the regulations of the relevant minister and internal standards included in the school bylaws and other internal school legal acts; 
5) international institutions and organisations, the state or party is or may become a member - this component can refer to e. g. the school's membership in an European network of cooperation, a pupil exchange programme etc.

If the above analogy is considered to be valid, then the question about the school's political culture also becomes valid. Following this line of thinking, in order to define a school's political culture, one must refer to the ready concept of political culture. A great multitude of such concepts may be found, and certainly, not every one of them may be applied to the specifics of a school. Analysing available literature, one may not that concepts of political culture created contemporaneously refer back or attempt to reinterpret or operationalise classical concepts. When looking at sources, analysed must be concepts created by classics: Gabriel Almond together with Bingham G. Powell (1975) and Sidney Verba (1963), and Vilfredo Pareto (1935/2017), who - despite having written about types of political thought, and not directly about political culture itself - may be interpreted within the same line of thinking (conf. Bäcker, 2005). Considering the fact that political culture does not remain indifferent against the broader cultural context of a specific country, one should note domestic Polish concepts as well. In this concept it was doubtless Zbigniew Blok $(2005,2009)$ who develop the concepts of political culture most broadly.

In order to find the concept of political culture most suited for the specifics of the school required the development of criteria to be fulfilled by such a concept. They helped to find the governing concept that may be subjected to further adaptation and applied to considerations about the school as an organisation having specific properties. These criteria are:

1) Generality: The selected concept should interpret the political system in such a way that it could be adapted to the organisational system of the school or that it would just consider the possibility of utilisation at levels lower than state-nation;

2) Detail focus: The selected concept should encompass the entire scope of possible forms of political culture (subjective and objective, material and intangible ones) and see the relations between them;

3) Specific attention: The selected concept should indicate specific components of political culture and use criteria to discern (but not valuate) the individual types of political culture, considering other systems than democracy;

4) Bilateral relations: The selected concept should not the influence of political culture on political structures and the influence of political structures on political culture; 
5) Relationality: The selected concept should consider the position and relations of political culture within general culture;

6) Operationalisation: The selected concept must yield the possibility of applying it empirically.

Each concept should be asked the same research questions in order to test whether it fulfils the above conditions:

1) What categories are used to describe political culture?

2) Which determining factors of political culture are noted?

3) What is the function of political culture?

4) What is the relationship between of political culture and culture in general?

5) What is the proposed typology of political cultures?

6) Which criteria of verification does it introduce?

The selected head concept should determine the scope of the subject of study to be adopted to fit the specifics of the school. At the same time, it shall allow the development of the definition of the school political culture, and thanks to the condition of operationalisation, it shall also allow the determination of the research tool used to classify its types. Below are presented the results of the analysed analysis for the following concepts: By Gabriel Almond together with Bingham G. Powell (1975) and Sidney Verba (1963), by Vilfredo Pareto (1935/2017) as interpreted by Roman Bäcker (2005) and by Zbigniew Blok (2005; 2009).

\section{The concept of political culture by Gabriel Almond, Bingham G. Powell and Sidney Verba}

\section{1) What categories are used to describe political culture?}

The authors see political culture as "psychological orientations with respect to social objects" (Almond, Verba, 1963: 14). The subject of study of political culture here are the attitudes of members of the given political system against objects of politics (Almond, Powell, 1966: 53). Political attitudes and orientations create potential political capacity for certain behaviour, and thus influence the functioning of the political system itself (Sobolewski, 2001: 130).

\section{2) Which are the determining factors of political culture?}

The authors note primarily external determining factors. They indicate three fundamental components of the attitude: knowledge, emotions and grades. Varied orientations: cognitive (dependent on the knowledge held) - evaluating 
(referring to the value system) and affective (based on own emotions) - imply various modes of behaviour by individuals in the same roles within the political system (Almond, Powell, 1975: 577). Individual knowledge, emotions and grades create potential political capacities, tendencies towards specific behaviour, thus influencing the operation of the political system itself (Sobolewski, 2001: 130). At the same time, they are dependent on the influence of this system: one's knowledge stems from learning and experiences, grades are based on an internalised value system conveyed within one's environment, the leading ideology or the media message.

\section{3) What is the function of political culture?}

In their work, the authors did not hide their approval for democratic governance. They determined to describe attitudes favourable for the democratic system, referring to the central criterion of the broadly understood participative attitude. In their work, considering only democratic societies, they created the ideal model - civic culture - indicating those of its functions like the support for and development of democracy. They noted the bilateral dependence of the type of political culture on the prevalent political system and the stability of the prevalent political system on the dominant type of political culture (Sobolewski, 2001: 130).

\section{4) What is the relationship between of political culture and culture in general?}

It is difficult to find thorough analyses of what politics is in the writings of Almond and his partners. They rather assume its common understanding $a$ priori.

The differentiation between political culture and a more general social culture system is analytical. Political culture is an integral aspect of more general culture, and the system of an individual's political convictions is only a part of the entirety of their convictions. Moreover, the fundamental convictions and patterns of cultural values that do not refer to particular political objects - usually play a significant role in the development of political culture. (Verba, 1956: 521)

Political culture is perceived in the anthropological perspective as a separate part of general culture. The adjective "political" simply narrows the field of research (on culture as a whole) to its scope covering a community's political relations, eliminating, for the purpose of research, other non-political aspects of a given group's culture. 


\section{5) What typology of political cultures does the concept propose?}

On the basis of the conducted research, the authors determined between three ideal types of political culture:

- narrow-minded political culture; it is characterised by low interest in issues of politics and limited political activity - described to be the right attitude towards the political system. Society does not assign any role to itself in political processes, it also does not see the meaning that politics has on individuals' lives. Narrow-minded political culture is closed to contacts with the outside world and is frequently based on stereotypes;

- subordinate political culture. It is characterised by subservience towards those in power. Despite society having knowledge on political entities and awareness of its significance in the system, it does not see the need to engage in politics, believing that this task lies with the elites of government. It is characterised by passivity in the development of public life, a lack of understanding of how political processes influence individuals' lives;

- participative political culture. Characterises a society with developed and stable convictions on the role of politics in the shaping of the lives of individual groups and individuals. Society is characterised by a high level of social activity, the awareness of opportunities brought about by active participation in political life (Almond, Verba, 1963).

The political culture of a society is in truth always a mix of various types - with the dominant type determining the assessment as a whole. Civic culture described by the authors is a mixed type, with prevalence of dominance of the participative culture and the retained and included components of types of subordinate and narrow-minded culture. This is a type of culture closer to the ideal, characteristic for systems of the United States and Britain (Wiatr, 1999).

\section{6) What are the criteria of verification in the study of types of political culture?}

Almond and Verba have conducted broad comparative studies of political attitudes of the societies of five countries: The United States, the United Kingdom, Germany, Italy and Mexico. The study "Civic Culture, Political Attitudes and Democracy in Five Nations" lists the questions to be asked to describe and characterise the political culture of a specific social group:

- what do participants know about their nation, political system, history, what is their emotional attitude towards the nation?

- what do they know about political institutions, the political game, leaders, what are their feelings towards them? 
- what do they know about mechanisms of politics, political decision processes, what is their perception of significant political events, such as elections, how to they assess them?

- how does the participant see themselves and their position within the political system, what are the emotions accompanying contact with the system? (Almond, Verba, 1963: 50).

Contemporaneously, this concept is accused of "expiry" of the explanatory value. The studies suggested by Almond and Verba were based on comparisons of the sought type of civic culture and its two crippled versions: the subordinate and narrow-minded ones. Remaining within the circle of democratic societies, the authors evaluated their detachment from the ideal. Contemporaneously, however, it is difficult to see democratic societies with the dominant types being the narrow-minded or subordinate type. Hence, this concept does not provide the capacity of empirical application in comparative studies any more (Blok, Pająk-Patkowska, 2016: 26).

\section{Types of social thinking by Vilfredo Pareto and the typology of political cultures}

The following concept of typology of political cultures was created by Roman Bäcker (2005) on the basis of the modified typology of political thought stemming from the classification of the types of social thinking described by Vilfredo Pareto (1994).

\section{1) What categories are used to describe political culture?}

Pareto derives the types of political thinking form the three modes of communication between people:

- communication for knowledge: based on analytical logic and verifiability of statements or, in the opposite, on quasi-science without care for logic and the reliability of the final results of a statement. The objective of this social thinking is the development of a model of truth, the provision of the feeling of certainty and permanence;

- communication for the satisfaction of residuals (Pareto, 1994: 165), own needs and aspirations. It is effected through mythical thinking creating derivations, or convictions and judgements, which should allow one to both exercise residuals and support social bonds. Exercising own needs in a manner acceptable by the social group. Mythical thinking allows the satisfaction of the needs of security and identity. It can take on the forms of religion, ide- 
ology or tribal thinking (contemporaneously post-tribal thinking) (Bäcker, 2005: 98-99);

- communication for want of social bonds. It is effected through communicative thinking described as "blah blah" or hearsay. The objective is purely the satisfaction of the need to belong by supporting social bonds. The opposite of communication thinking is vegetative thinking, whereby the sole objective of an individual is direct and fastest satisfaction of its own life needs, in particular biological ones (Pareto, 1994).

Each of the above types of thinking is related to a personality model. Roman Bäcker derives from them the type of political thinking and (...) types of political culture. Political culture is a thing of awareness, and plays the role of a buffer. Political culture may be described in the category of action-reaction to the political stimulus - dependent on the characteristics of this buffer that is political thinking. The subject of studies on political culture would hence be observable actions: of individuals, groups, parties, those exercising governance and those being governed, and not their declarations.

\section{2) Which are the determining factors of political culture?}

The type of political culture is determined by modes of social thinking and by personality models, remaining compatible with them as follows: one's personal model influences their type of social thinking, implying the type of political culture that they represent (Bäcker, 2005: 102). Pareto shows, how strong and how irrational are the motives of social activity. He introduces the concept of residuals as eternal motivational dispositions existing in human nature and rooted in instincts, emotions and passions present even in highly abstract theories created by "pure" intellect (Pareto, 1994, p. 165). Every political structure promotes specific personal patterns, however, the efficiency of their takeover by individuals depends on individual dispositions (Bäcker, 2005: 101).

\section{3) What is the function of political culture?}

As interpreted by Roman Bäcker, political culture is the link that binds properties of personality, the relevant type of social thinking, with the world of knowledge, feelings and political will (Bäcker, 2005: 102).

\section{4) What is the relationship between of political culture and culture in general?}

Pareto describes types of social thinking based on modes of communication between people as being determined by three criteria: knowledge, the will to satisfy 
own needs and aspirations and the need of social bonds (Pareto, 1994: 165). From this general perspective, based on certain characteristic properties of human nature, Roman Bäcker first derived types of political thinking and then types of political cultures. The type of political culture is thus compatible with the broader context, with a specific type of thinking and with the personality model that determines all spheres of social activity, not just the political. It is worth noting that the typology by Pareto and Bäcker is independent from the democratic system. Some of the described types of political culture are characteristic for non-democratic societies/groups, some may come to shine both in democratic as well as non-democratic systems.

\section{5) What typology of political cultures does the concept propose?}

Analysing the concepts of Vilfredo Pareto, Roman Bäcker derives the following types of political culture from them:

- vegetative type of political culture. The individual representing this type of culture perceives the world only from the perspective of their own profits and losses, not considering possible, future consequences. They are characterised by a high degree of conformism and a lack of rules. They are able to do anything that it would consider advantageous for themselves at any given moment. In democratic systems, such an individual will represent an attitude of withdrawal, however, may be easily activated encouraged by material advantages. In totalitarian systems, the individual will be active (bureaucratically) subordinated, not showing any type of rebellious behaviour (Bäcker, 2005: 102-103);

- post-tribal type of political culture. Individuals representing this type of culture strive to achieve advantages for the group at the expense of the social environment. They treat social standards relatively, depending on whether they apply to "us" or "them". This type may be found in all kinds of political systems, however, most commonly in authoritarian governance structures (more frequently at the local than at the state level) (Bäcker, 2005: 103);

- tribal type of political culture. Individuals representing this type of culture are resistant to upgrade processes. They rely on modes of behaviour towards and within governance structures passed down by generations, both within a given group as well as with respect to the outside. The conveyed rituals rely on white and black, schematic perceptions of the world. This type was represented in the $20^{\text {th }}$ century by the Italian mafia (Bäcker, 2005: 103); 
- rationalised-mythical political culture type. Individuals representing this type of culture are characterised by the skill to fuse individual interests with group interests. They make attempts at exercising them simultaneously. This culture is based on coincident ideological or religious thinking and Aristotelian knowledge. The fundamental condition is the basis of tolerance, appreciation of difference and the right to subjectivity of others. Political struggle is perceived as a game with the result being one or zero. This culture is characteristic for the open society (Popper, 1987). It may be compared to the civic culture of the democratic society (Bäcker, 2005: 103-104);

- fundamentalist political culture type. This is a community of cultures which struggles, within a rapidly changing, developing society, strives to maintain traditional patterns of social life. This type of culture is counterculturalist, nativist at times. It emerges under the strong influence of contemporary derivations utilising e. g. the phraseological resources of universalist religions or traditional political behaviour models (Bäcker, 2005: 104);

- totalitarian type of political culture. Its core is political gnosis. An individual representing this type of culture rises best in the context of vegetative or post-tribal culture. It is characterised by a revolutionist or hyperactivist personality model (Bäcker, 2005: 104).

\section{6) What are the criteria of verification in the study of types of political culture?}

The concept of Vilfredo Pareto is a sociological one, best used together with the method of observation of behaviour, activities and actions that are the subject of study of political culture. Some authors, however, note certain ambiguities in the concept of Pareto concerning the definition of residuals so significant in the qualification of types of social thinking and political culture. The work by Pareto includes many disjointed interpretations of this concept. At one point, he likens this to instinct (Pareto, 1994: 165), elsewhere with feeling (Pareto, 1994: 204). At the same time, he believes that residuals, even if indirectly related to feelings and instinct, are at the same time dissimilar from them because "feelings are expressed through residuals" (Pareto, 1994: 169). Explaining the causes of observed behaviour, one cannot refer to objectively analysable components of reality, but only to intuitive categorisations. Pareto explains all activities (including political activities) by a relevant combination of residuals. Hence, if one does not have a common definition of residuals, one does is actually not able to verify the concepts of this author (Szczepański, 1961: 298). 


\section{The concept of political culture by Zbigniew Blok}

\section{1) What categories are used to describe political culture?}

Within the concept of Zbigniew Blok, political culture is treated as a filter modifying various systemic stimuli such as: compulsion, authority, manipulation, propaganda or advertising and leading to specific political behaviour being the subject of study through the researcher's observations. Political culture thus belongs to the sphere of consciousness. It is a part of social awareness, individual awareness, which allows the elimination, prioritisation or modification of own behaviour and political decisions as well as modelling societal/ political roles, both in those exercising power as well as those being governed (Blok, 2005: 52).

\section{2) Which are the determining factors of political culture?}

The author determines between four basic modules of the structure of awareness making up the scope of political culture. These are:

- political ideals, values and norms - internalised and shared as well as consciously rejected;

- political habits, traditions and models (-) supporting the political system and not supporting the political system;

- emotions towards the subjects and objects of politics - positive and negative ones;

- criteria of assessment of political facts, phenomena and processes (-) preferring the interest of society as a whole, the interest of social groups and the interests of individuals (Blok, 2005: 53).

The determination of the type of political culture of an individual is the determination, where the individual is located within the described space of extreme determining factors for each of these planes. This position is dependent on the internalised values, norms and ideas, past life experience, experienced historical conditions, climate and geographic conditions or the economic conditions of life.

\section{3) What is the function of political culture?}

The same political stimulus, depending on the character if the filter, causes different reactions. The influence of the stimulus hence generates a certain pool of possible political behaviour patterns and possible modes of thinking about politics. Only certain possible reactions from this pool are processed by the filter of "political culture", dependent on the character of the filter. Behaviour considered to be unwanted, unsuitable, unworthy, etc., is eliminated. Subsequently, the be- 
haviour that makes it through is ordered according to the priority hierarchy as determined by the character of the filter (Blok, 2009: 100). It is thus a function of political culture to "eliminate, modify or order political behaviour and decisions" (Blok, 2009: 101).

\section{4) What is the relationship between of political culture and culture in general?}

The author does not directly refer to the correlations of political culture with culture in general. He recalls the definitions of Antonina Kłoskowska. She considers culture to be a multi-aspectual whole, within which we may determine the following:

- the layer of internalised norms, patterns and values found within human conscience;

- the layer of activities being the expression of internalised norms, patterns and values;

- the layer of products and objects becoming the subject of cultural activity;

- the layer of thought types, e.g. language (Kłoskowska, 1981: 108-117).

Zbigniew Blok stresses on multiple occasions the possibility of expansion of the indicated scope of determining factors of political culture perceived it seems, as the internalised layer of human conscience stemming from general culture (Blok, 2009: 89).

\section{5) What typology of political cultures does the concept propose?}

The author operationalises each of the four constituent components of conscience, determining and defining the four fundamental modules of political culture, and describing for each of these the end points (-) dimensions. In this manner, within the first module, created by political ideas, values and norms, the following dimensions can be determined:

- individualism-collectivism (the priority of the good of the individual over the good of the group, and vice versa);

- freedom-equality (the priority of the freedom of action or the priority of equal treatment);

- justice-injustice (treating others the same way on the basis of the same moral criteria or treating others differently on the basis of random criteria).

The second module is made up by political habits, traditions and models. The dimensions for this module suggested by the author are:

- democracy-totalitarianism (the attitude of citizens towards democratic solutions); 
- tolerance-intolerance (perception of difference, otherness, and attitude towards others);

- elitarism-egalitarianism (the attitude towards hierarchy in social structures).

The third module describes emotions towards politics, it is made up of the following dimensions:

- agreement-struggle (attitude of agreement perceived as an important social good versus an attitude of rivality, the striving for confrontation);

- patriotism-cosmopolitism (attachment to one's own country or its lack and the feeling of attachment to a broader community);

- fundamentalism-nihilism (basing oneself on ideas embedded in conscience and entire relativism of values and ideas);

- voluntarism-fatalism (perception of the decisive influence of an individual on history or lack thereof);

- pessimism-optimism (perceiving events in a negative or positive manner).

The last (fourth) module is made up of assessment of politics, or the criteria used by society to evaluate the actions of subjects of politics. In this regard one can discern between the following dimensions:

- just-unjust (actions following the criteria of assessment or violating them);

- efficient-effective (actions achieving the effect at lowest cost or actions achieving the effect irrespective of costs);

- objectivised-discretionary (assessment on the basis of clearly defined or random criteria);

- rational-irrational (assessment based on precise criteria versus assessment dependent on an individual's emotional condition) (Blok, 2005: 116-118).

Blok creates out of concepts thus operationalised a typology map of political culture, allowing him to place an individual on a ten-point scale between the extremes of every dimension for all the assumed modules. This yields the possibility of calculation of the mean significant for the purpose of determination of the dominant type. The author considers the possibility of further empirical expansion of the concept of political culture by further modules (e.g. attitudes towards political activity) as well as of a thorough analysis of just one dimension chosen by the researcher. In addition, each module can be expanded to include further dichotomies depending on the assumed methodological and theoretical assumptions. Thanks to this, the researcher may of their own accord expand the typological matrix, however, always adhering to a certain rigid, testable system. 


\section{6) What are the criteria of verification in the study of types of political culture?}

The concept describes precisely the subsequent stages of operationalisation and verification: the precise definition of the modules of culture and the concept dichotomies, translating them into a language understandable by the studied persons, recording them in the form of a descriptive representation of the ends of the scale, the execution of pilot studies, the collection of data from the study proper. On the basis of the suggested empirical data, it may be determined, where within the space of extreme factors determining the modules of culture can an individual be located. According to the derived formula, its individual type of political culture may be determined. It is only then, having determined who is the carrier of political culture and when, can generalisations be derived, with ideal types or models being created.

Summarising the analysis and the compilation in the table, one can conclude as follows. Condition one: Generality, meaning, such an interpretation of the political system so that it could be applied at a level lower than state-nation, is fulfilled by the concepts of Blok and Pareto. The concept of Pareto initially concerned itself with social thinking, possibly simplifying its application in school space using the adaptation by Roman Bäcker for these dimensions of social life that are political in character (according to the function of political culture as a vehicle). The concept by Blok, due to the openness of the scheme of typologies for the individual researcher, allows discussion of political culture on various levels of social complexity: for the social group, the nation, for complex societies, depending on the assumed theoretical and methodological assumptions.

All three concepts fulfil the condition of detail, covering the entire scope of all possible signs of political culture. The criteria of differentiation between various types of political culture are antinomic within them. In this regard, the concept of Pareto lacks clarity of definition, in particular the residuals introduced by the author, which, in various parts of the text, are interpreted differently. Such blurring of definitions will certainly hinder adaptation of the concept to school conditions. The classifications by Almond and Blok are based on divisible, boundary-defined ideal types (Almond), or by extremes (Blok). However, it is worthwhile to quote the fault voiced against the concept developed by Almond, as referring only to democratic systems, not considering the political behaviour of other communities, in particular those outside of the sphere of societies of Latin culture (Bäcker, 2005: 97). 
Table 1. The comparison between the analysed concepts of political culture in line with the analytical questions put forward

\begin{tabular}{|c|c|c|c|}
\hline Analysis criteria & G. Almond & V. Pareto & Z. Blok \\
\hline $\begin{array}{l}\text { Descriptive } \\
\text { categories of } \\
\text { political culture }\end{array}$ & $\begin{array}{l}\text { Psychological orientation. } \\
\text { Subject of study: attitudes. }\end{array}$ & $\begin{array}{l}\text { Reaction to the political } \\
\text { impulse. } \\
\text { Subject of study: actions/ } \\
\text { behaviour. }\end{array}$ & $\begin{array}{l}\text { Filter between stimulus } \\
\text { and reaction. } \\
\text { Subject of study: Behav- } \\
\text { iour. }\end{array}$ \\
\hline $\begin{array}{l}\text { Determining } \\
\text { factors of politi- } \\
\text { cal culture }\end{array}$ & $\begin{array}{l}\text { Knowledge, emotions, } \\
\text { grades. }\end{array}$ & $\begin{array}{l}\text { Personal role model }+ \\
\text { type of social thinking. }\end{array}$ & $\begin{array}{l}\text { - ideas, values, norms; } \\
\text { - habits, traditions, } \\
\text { customs; } \\
\text { - emotions; } \\
\text { - assessment criteria. }\end{array}$ \\
\hline $\begin{array}{l}\text { Functions of } \\
\text { political culture }\end{array}$ & $\begin{array}{l}\text { Support for and develop- } \\
\text { ment of democracy. }\end{array}$ & $\begin{array}{l}\text { Link binding traits of per- } \\
\text { sonality, the type of social } \\
\text { thinking and the world of } \\
\text { politics. }\end{array}$ & $\begin{array}{l}\text { Elimination, ordering, } \\
\text { modification of political } \\
\text { behaviour and decisions. }\end{array}$ \\
\hline $\begin{array}{l}\text { Relation } \\
\text { between the } \\
\text { political culture } \\
\text { and general } \\
\text { culture }\end{array}$ & $\begin{array}{l}\text { Political culture as a } \\
\text { separate (narrower) part } \\
\text { of general culture. }\end{array}$ & $\begin{array}{l}\text { Political culture is an as- } \\
\text { pect of a broad context of } \\
\text { social activity determined } \\
\text { by the personal model } \\
\text { and type of thinking. }\end{array}$ & $\begin{array}{l}\text { Political culture is derived } \\
\text { from culture in general. }\end{array}$ \\
\hline $\begin{array}{l}\text { Typology of po- } \\
\text { litical culture }\end{array}$ & $\begin{array}{l}\text { - narrow-minded; } \\
\text { - subordinate; } \\
\text { - participatory. } \\
\text { * typology created for } \\
\text { the study of democratic } \\
\text { systems allows the deter- } \\
\text { mination of the distance } \\
\text { between the dominant } \\
\text { culture and the participa- } \\
\text { tive ideal. }\end{array}$ & $\begin{array}{l}\text { - Vegetative; } \\
\text { - post-tribal; } \\
\text { - tribal; } \\
\text { - rationalised-mythical; } \\
\text { - fundamentalist; } \\
\text { - totalitarian. } \\
\text { * the typology spans dem- } \\
\text { ocratic and non-demo- } \\
\text { cratic systems. }\end{array}$ & $\begin{array}{l}\text { The typology presented } \\
\text { in the space of extreme } \\
\text { factors determining the } \\
\text { individual modules and } \\
\text { their ranges is precise yet } \\
\text { open and individualised. } \\
{ }^{\star} \text { No relation to political } \\
\text { systems. }\end{array}$ \\
\hline $\begin{array}{l}\text { Verification } \\
\text { criteria }\end{array}$ & $\begin{array}{l}\text { - interviews concerning } \\
\text { knowledge, emotions } \\
\text { and respondent assess- } \\
\text { ments. Comparative } \\
\text { studies. }\end{array}$ & $\begin{array}{l}\text { - observation of behav- } \\
\text { iour/ activities/ activity. }\end{array}$ & $\begin{array}{l}\text { Self-assessment question- } \\
\text { naire as part of four basic } \\
\text { awareness modules along } \\
\text { a } 10 \text {-level scale + behav- } \\
\text { iour observation. }\end{array}$ \\
\hline
\end{tabular}

Source: own work

All concepts fulfil the condition of relationality and consider the condition of the bidirectional relation (taking into account such processes as internalisation, socialisation, past life experience: historic, social or economic ones). Even though the concept of Almond seems to insufficiently consider possible social and psychological processes taking place between the statement of attitudes and the actual 
behaviour of individuals; in his research, the author considers statements, not actions. All concepts indicate specific components of political culture and indicate their types. However, only the concept by Blok completely avoids the condition of non-valuation. The concept of Almond presents the type of participative culture to be the model one, describing the distance of the other ideal as well as actual types from it. The concept of Pareto suggests the rational-mythical culture type to be the desired one. Both for Almond and Pareto, the types of political culture are characterised as being ideal. The authors first performed their research, and then, on this basis, developed certain ideal types - models of culture. Blok suggests a different approach. He first operationalises each of the four constituent components of political culture, determining for them boundary points, and then, using concepts operationalised in this way, be creates a map of typologies of political culture, allowing the placement of an individual between extremes assigned to every category, to every component. We are thus able to distinguish between a great number of types of political culture. Every one of them is individualised and may be individually modified, expanded by the researcher. Considering the scope and the possibility of adaptation for smaller communities and their systems of political organisation (e.g. schools), both the concept of Pareto (with its adaptation by Roman Bäcker) as well as the concept of Zbigniew Blok seem fitting. However, considering the ultimate condition, that of operationalisation, it is the concept of Zbigniew Blok that must be chosen, because, as already indicated above, the concept of Pareto brings about certain interpretational difficulties, hence, it cannot be precisely operationalised.

The results of the theoretical metaanalysis indicated that the leading concept of political culture - fulfilling the determined criteria to the greatest extent - is the one by Zbigniew Blok $(2005 ; 2009)$. The concept proposed by him provides the possibility of individual determination of the type of political culture of each individual through its placement along a ten-point stale of every dimension of all the assumed modules, along with the possibility of calculation of the mean significant for the determination of the dominant type. It is not based on ideal types, hence, it avoids valuation. Such an approach yielding a precise and rigid yet open scheme shall prove itself during an adaptation on various levels of social complexity, the organisation of which would gain a political form.

The author of the concept notes the significant issue concerning the shift to the stage of formulation of concepts understandable for the person being analysed. He suggests specific formulae of interview questions, recommends pilot studies aimed at verifying the comprehension of abstract terms. Within the concept of usage of the concept of political culture at the school level, this issue is reminds 
one of the additional need of wording the interview questions in such a way so that they would clearly indicate the relation towards the school system. Hence, for instance, for the first module, composed of political ideas, values and norms, the author distinguishes between three fundamental dimensions:

- individualism-collectivism, determining the preference of the good of the individual over the general good, and vice versa;

- freedom-equality, determining the priority of freedom of action over equal treatment, and vice versa;

- justice-injustice, determining the need to treat people the same way on the basis of the same criteria, or differently, on the basis of random criteria.

We can create, for the presented dimensions, in line with the guidelines of the author of the concept, statements comprehensible for the analysed persons in the form of a descriptive representation of the boundaries of a given scale. For the school community this could be e.g.:

- At my school, it is most important for me to follow my own passions and take care of my business (individualism). At school, one needs to keep in mind the good of groups we belong to (class, circle of interests), sometimes one has to forgo one's objectives (collectivism).

- It is important for me to feel that all pupils are treated justly (justice). The way other pupils from my school are treated is not important to me (injustice).

- At school, it is most important for pupils to be able to freely act in various areas (freedom). At school, it is most important for equality to be maintain in various areas (equality).

And so forth, in a similar manner for all the other modules, to implement the assumption as worded by Maria Dudzikowa that

(...) a school's culture is a set of ideas, attitudes, rules and practices of a school, which, in a covert or overt way, influence an individual's development and social change, both within the time-space of the school as well as in its direct and indirect vicinity. A school's culture perceived as such is composed of the cultures of its subjects interactively bound with it: teachers, pupils, the "non-paedagogical" staff of the school and the parents. Local, regional and global processes doubtless come into play here as well. (Dudzikowa, Bochno, 2016: 6)

\section{Bibliography}

Almond G., Powell G.B. (1966), Comparative Politics: a Developmental Approach; an analytic study, Boston.

Almond G., Powell G.B. (1975), Kultura polityczna, [in:] W. Derczyński, A. Jasińska-Kania, J. Szacki (eds.), Elementy teorii socjologicznych, Warszawa. 
Almond G., Verba S. (1963), The Civic Culture, Political Attitudes and Democracy in Five Nations, Princeton.

Bäcker R. (2005), Typy myślenia społecznego Vilfredo Pareto a typologia kultur politycznych, [in:]

Z. Blok (ed.), Teoretyczne i metodologiczne problemy badań nad kultura polityczną, Poznań.

Blok Z. (2009), O polityczności, polityce, politologii, Poznań.

Chmaj M., Żmigrodzki M. (1996), Wprowadzenie do teorii polityki, Lublin.

de Lazari A. (2016), Czy brak kultury też jest kulturą, [in:] A. Sarnacki (ed.), Kultura polityczna jako przedmiot badań, Kraków.

Dernowska U., Tłuściak-Delikowska A. (2015), Kultura szkoły. Studium teoretyczno-empiryczne, Kraków.

Dymara B. (2009), Dziecko w świecie edukacji, Kraków.

Dudzikowa M., Bochno E. (2016), Wprowadzenie do serii “Kultura Szkoły”, [in:] M. Dudzikowa, S. Jaskulska (eds.), Twierdza. Szkoła w metaforze militarnej. Co w zamian?, Warszawa.

Ferejohn J., Rakove J., Riley J. (2001), Constitutional Culture and Democratic Rule, Cambridge.

Kłoskowska A. (1981), Socjologia kultury, Warszawa.

Pareto V. (2017 [1935]), The Mind and Society, New York.

Podolak M., Żmigrodzki M. (2013), System polityczny i jego klasyfikacje, [in:] M. Żmigrodzki, B. Dziemidok-Olszewska (eds.), Współczesne systemy polityczne, Warszawa

Sarnacki A. (2016), Wstęp, [in:] A. Sarnacki (ed.), Kultura polityczna jako przedmiot badań, Kraków.

Sobolewski M. (2001), Pisma nieznane i rozproszone, Kraków.

Szczepański J. (1961), Socjologia. Rozwój problematyki i metod, Warszawa.

Wiatr J.J. (1999), Socjologia polityki, Warszawa.

Wildawski A. (1995), Kulturowa teoria przywództwa, [in:] J. Szczupaczyński (wyb.), Władza i społeczeństwo. Antologia tekstówz socjologii polityki, Warszawa.

Verba S. (1965), Comparative political culture, [in:] L. Pye, S. Verba (eds.), Political Culture and Political Development, New York.

Zieliński E. (1999), Nauka o państwie i polityce, Warszawa. 
